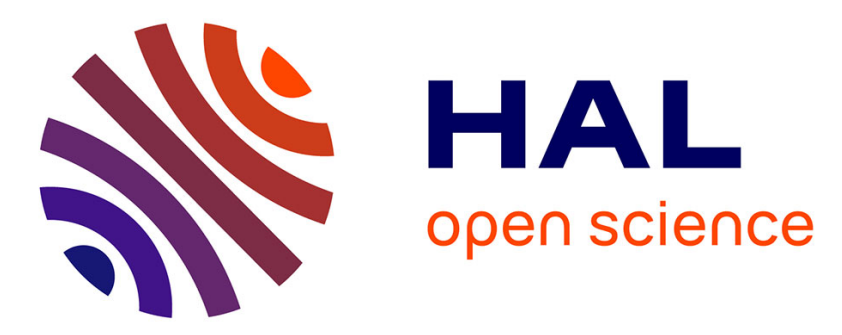

\title{
Specificity and success of oral-bait delivery to Eurasian wild boar in Mediterranean woodland habitats
}

Cristina Ballesteros, Joaquín Vicente, Ricardo Carrasco-García, Rafael Mateo, José Fuente, Christian Gortázar

\section{To cite this version:}

Cristina Ballesteros, Joaquín Vicente, Ricardo Carrasco-García, Rafael Mateo, José Fuente, et al.. Specificity and success of oral-bait delivery to Eurasian wild boar in Mediterranean woodland habitats. European Journal of Wildlife Research, 2010, 57 (4), pp.749-757. 10.1007/s10344-010-0483-9 . hal00654146

\author{
HAL Id: hal-00654146 \\ https://hal.science/hal-00654146
}

Submitted on 21 Dec 2011

HAL is a multi-disciplinary open access archive for the deposit and dissemination of scientific research documents, whether they are published or not. The documents may come from teaching and research institutions in France or abroad, or from public or private research centers.
L'archive ouverte pluridisciplinaire HAL, est destinée au dépôt et à la diffusion de documents scientifiques de niveau recherche, publiés ou non, émanant des établissements d'enseignement et de recherche français ou étrangers, des laboratoires publics ou privés. 


\title{
Specificity and success of oral-bait delivery to Eurasian wild boar in Mediterranean woodland habitats
}

\author{
Cristina Ballesteros • Joaquín Vicente • \\ Ricardo Carrasco-García $\cdot$ Rafael Mateo • \\ José de la Fuente • Christian Gortázar
}

Received: 29 April 2010 /Revised: 13 October 2010 /Accepted: 1 December 2010 /Published online: 21 December 2010

(C) Springer-Verlag 2010

\begin{abstract}
Eurasian wild boar (Sus scrofa) is an important reservoir host for pathogens affecting humans and domestic animals. The eradication of these diseases may require the development of control strategies that reduce pathogen transmission between wildlife and domestic animals. Baiting for oral vaccine delivery is often considered for wildlife disease control. The effective and efficient field vaccination of wildlife requires species-specific baits as delivery vehicles for oral vaccines and designing appropriate baiting strategies. The objective of this study was to determine the proportion of young and adult wild boar and non-target animals that consumed baits containing a chemical marker, iophenoxic acid (IPA), in delivery trials conducted in summer in four different sites in the Mediterranean region of Spain where wild boar are abundant. The proportion of wild boar showing IPA markers in serum in autumn ranged from $11.5 \%$ to $56.4 \%$. When attending to age classes, $12.6 \%$ to $72.7 \%$ of young individuals presented IPA. The results evidenced that the percent of wild boar that ingested the baits varied among study sites and age classes. Placing
\end{abstract}

\footnotetext{
Communicated by H. Kierdorf

C. Ballesteros $(\bowtie) \cdot J$. Vicente $\cdot$ R. Carrasco-García $\cdot$ R. Mateo

J. de la Fuente $\cdot \mathrm{C}$. Gortázar

Instituto de Investigación en Recursos Cinegéticos

(IREC) (CSIC-UCLM-JCCM),

Ronda de Toledo $s / n$,

13005 Ciudad Real, Spain

e-mail: Cristina.Ballesteros@uclm.es

C. Ballesteros

e-mail: Cristina.ballesteros@irec.csic.es

J. de la Fuente

Department of Veterinary Pathobiology, Center of Veterinary

Health Sciences, Oklahoma State University,

Stillwater, OK 74078, USA
}

baits inside selective cages (for juveniles) and under heavy pavel stones (for adults) contributed to improve age specificity in bait consumption. We suggest ways for improving the age specificity of bait delivery systems used for young and adult wild boar.

Keywords Bait - Bovine tuberculosis · Iophenoxic acid · Vaccine $\cdot$ Wild boar

\section{Introduction}

Eurasian wild boar (Sus scrofa) are key wildlife reservoir hosts for diseases affecting livestock, such as classical swine fever (Kaden et al. 2005), and Aujeszky's disease (Ruiz-Fons et al. 2008), as well as for several zoonotic diseases including bovine tuberculosis (bTB; Naranjo et al. 2008). The total eradication of a disease is very difficult if a wildlife host is able to serve as a natural reservoir of the pathogen (Gortázar et al. 2007). Hence, the eradication of diseases shared between livestock and wildlife may require the development of control strategies that reduce pathogen transmission between wildlife and domestic animals using vaccination or by reducing host density (Brauer et al. 2006; Ballesteros et al. 2007; Cross et al. 2007).

Along with hunting, live-trapping, and habitat management, control of both wild boar and feral pigs may be achieved through baiting with baits containing poison (McIlroy et al. 1989; Saunders et al. 1990; Cowled et al. 2006; Twigg et al. 2007) or contraceptives (Linhart et al. 1997). Baiting with oral vaccines is also used for wildlife disease control (Baer 1976; Cross et al. 2007). However, the effective and efficient field vaccination of wildlife species requires the development of stable and speciesspecific baits as delivery vehicles for oral vaccines (Brauer 
et al. 2006; Ballesteros et al. 2007) and designing appropriate baiting strategies (Vos et al. 2008). In Spain, controlled vaccination trials are being conducted to eventually use wildlife vaccination as a disease management tool for Aujeszky's disease (Ruiz-Fons et al. 2008) and bTB (Ballesteros et al. 2009c). Additionally, we developed oral baits suitable to deliver pharmaceuticals to free-living wild boar, and developed techniques to improve specificity and uptake rate in overabundant wild boar populations (Ballesteros et al. 2009a). These baits could be used for the oral immunization of 2-4-month-old wild boar piglets (Ballesteros et al. 2009b).

Chemical markers are incorporated into baits to enable identification of individuals consuming baits. Substances like rhodamine $\mathrm{B}$, tetracycline, and iophenoxic acid (IPA) have been used as markers in bait delivery experiments (Fletcher et al. 1990; Farry et al. 1998; Fleming et al. 2000). Iophenoxic acid ( $\alpha$-ethyl-2-hydroxy-2,4,6-triiodebenzenepropanoic acid; hereafter Et-IPA) was clinically employed as a cholecystographic medium in 1950s due to its low systemic toxicity and low level of unpleasant side reactions (Shapiro 1953). However, it was proven to cause prolonged elevation of serum iodine levels so it was withdrawn from clinical use in 1957 because of its long persistence in plasma. The plasma half-life in humans is of the order of 2.5 years (Astwood 1957).

Recently, Et-IPA has been used successfully to investigate wild boar baits and baiting strategies to deliver oral vaccines, contraceptives, and toxicants (Fletcher et al. 1990; Mitchell 1998; Fleming et al. 2000; Campbell et al. 2006; Cowled et al. 2008; Massei et al. 2009). Et-IPA can be incorporated into baits as a chemical marker because it binds to proteins in the blood plasma and elevates the protein-bound iodine in animals that consume Et-IPA-marked baits. Percentages of wild boar and feral pigs sampled in the sites where Et-IPA-marked baits have been distributed vary from $31 \%$ (in one of the three study sites of Fleming et al. (2000)) to 95\% (Fletcher et al. 1990). Mitchell (1998) found
$63 \%$ of adult feral pigs eating marked baits whereas Campbell et al. (2006) and Cowled et al. (2006) reached $74 \%$ and $73 \%$ of the feral pigs sampled, respectively.

Determination of the proportion of wild boar and nontarget animals consuming baits is crucial to optimize and evaluate the cost and success of baiting campaigns. Moreover, we hypothesized that age-specific delivery could be achieved by deploying baits in special cages or under heavy stones. The aim of this study was to determine the proportion of young and adult wild boar and non-target animals consuming two kinds of marked baits (one directed to adult wild boar and another targeting wild boar up to 8 months old) in a bait delivery trial conducted at four different sites in the Mediterranean region of Spain where wild boar are abundant.

\section{Materials and methods}

\section{Study sites}

Experiments were conducted in four hunting estates in the provinces of Toledo: Quintos de Mora estate (403926 E; $4361344 \mathrm{~N} ; 68.6 \mathrm{~km}^{2}$; site 1); Ciudad Real: Riofrio (371401 E; $4326485 \mathrm{~N} ; 32.7 \mathrm{~km}^{2}$; site 2) and Rosario (378481 E; $4326095 \mathrm{~N} ; 20.9 \mathrm{~km}^{2}$; site 3) estates; and Guadalajara: CM estate $\left(581715 \mathrm{E} ; 4517113 \mathrm{~N} ; 11.0 \mathrm{~km}^{2}\right.$; site 4), Castilla-La Mancha, central Spain. Sites 1 and 4 are fenced, thus making them almost impermeable for ungulate immigration or emigration. Sites 2 and 3 are quite permeable so movements of animals are more likely.

The study sites were selected to be representative of the wide range of wild boar abundances that can be found in South Central Spain. A population of 400 wild boar was estimated according to manager interviews in site 1 whereas the population of wild boar estimated at sites 2,3 , and 4 was of 200 individuals for each site (Table 1). These

Table 1 Estimated population size and density of feeders and pavel stones used to deploy the baits at each site

\begin{tabular}{|c|c|c|c|c|c|c|}
\hline Site & Area $\left(\mathrm{km}^{2}\right)$ & $\begin{array}{l}\text { Pre-baiting } \\
\text { period }\end{array}$ & No. of wild boar & $\begin{array}{l}\text { Abundance } \\
\text { index }\end{array}$ & No. and density of feeders & No. and density of pavel stones \\
\hline 1 & 68.6 & 5 weeks & 400 & 0.17 & $\begin{array}{l}30 \\
4.4^{\mathrm{a}} / 25.9^{\mathrm{b}}\end{array}$ & $\begin{array}{l}86 \\
12.5^{\mathrm{a}} / 73.5^{\mathrm{b}}\end{array}$ \\
\hline 2 & 32.7 & 3 weeks & 200 & 0.05 & $\begin{array}{l}16 \\
4.9^{\mathrm{a}} / 98.0^{\mathrm{b}}\end{array}$ & $\begin{array}{l}54 \\
16.5^{\mathrm{a}} / 330^{\mathrm{b}}\end{array}$ \\
\hline 3 & 20.9 & 3 weeks & 200 & 0.20 & $\begin{array}{l}14 \\
6.7^{\mathrm{a}} / 33.5^{\mathrm{b}}\end{array}$ & $\begin{array}{l}48 \\
23.0^{\mathrm{a}} / 115^{\mathrm{b}}\end{array}$ \\
\hline 4 & 11.0 & $>5$ weeks & 200 & 0.28 & $\begin{array}{l}6 \\
5.4^{\mathrm{a}} / 19.3^{\mathrm{b}}\end{array}$ & $\begin{array}{l}50 \\
45.4^{\mathrm{a}} / 162^{\mathrm{b}}\end{array}$ \\
\hline
\end{tabular}

\footnotetext{
${ }^{\mathrm{a}}$ Feeders or pavel stone density per $10 \mathrm{~km}^{2}$

${ }^{\mathrm{b}}$ Feeders or pavel stone density per wild boar, calculated as [feeders or pavel stone density per $10 \mathrm{~km}^{2}$ ] $\div$ [wild boar abundance index]
} 
estimates were in agreement with our own independent estimates of wild boar relative abundance based on the dropping frequency index. Briefly, each count consisted of $n=40$ transects of $100 \mathrm{~m}$, divided into ten sectors of $10 \mathrm{~m}$ in length. Dropping frequency was defined as the average of the number of $10-\mathrm{m}$ sectors with wild boar droppings in each transect of $100 \mathrm{~m}\left(\mathrm{DF}=\sum D \mathrm{i} / n\right.$; where " $D$ " is the number of dropping-positive sectors and ranges from zero to ten, and " $n$ " is the number of $100-\mathrm{m}$ transects, usually 40 per site; Acevedo et al. 2007; see Table 1).

Artificial selective feeders were evenly distributed across the sites 1, 2, and 3. Site 4 had its own feeders since artificial feeding is routinely practiced in this estate. Feeder density ranged from 4.4 to 6.7 per $10 \mathrm{~km}^{2}$ and from 19.3 to 98.0 per wild boar (Acevedo et al. 2007; Table 1). Feeders were placed close to water holes (which is a limiting resource in summer in the study areas) or using already existing feeding points (site 4).

Artificial feeders consisted of a 1-cm- $\varnothing$ metal-grid cage with an opening (15-cm wide) to allow only access of piglets younger than 5 months (Fig. 1). A green mesh that provides shade covered the cage. Each feeder (triangular shape, side $=1 \mathrm{~m}$ ) was pre-baited with pelleted piglet feed and maize to accustom animals to visit them. There was the possibility to combine two grids per side to get an extra 30-cm-wide opening, which allowed access to wild boar up to 8 months.

Heavy pavel stones were placed outside the feeders. Pavel stone density ranged from 12.5 to 45.4 per $10 \mathrm{~km}^{2}$ and from 73.5 to 330 per wild boar abundance index (Table 1). Each stone weighed $7 \mathrm{~kg}$ and measured $34 \times 9 \times 20 \mathrm{~cm}$. The stones had a hollowed shape so feed could be placed under them. The stones were slightly buried in the ground in order to restrict access to all but adult wild boar, which could turn them and access the feed and baits placed below.

Half of the total artificial feeders in each site were monitored with digital game cameras with infrared illumination (Leaf River Outdoor Products, Taylorsville, MS, USA). Cameras were set on either native vegetation (tree trunks or branches) or artificial structures (e.g., fence posts).

Although it has been previously reported that metal-grid selective feeders improve age-related bait specificity and uptake rate in wild boar populations accustomed to being fed by managers (Ballesteros et al. 2009a, b), in the present study, we targeted $<8$-month-old wild boar (approximately $30-\mathrm{kg}$ weight in the study area) because at the time the trial was performed, the largest proportion of the last wild boar cohort was between 4 and 8 months old. Sites 1 and 4 were pre-baited for 5 weeks, and sites 2 and 3 were pre-baited for 3 weeks. Every 3 days, we checked them to record feed consumption and pictures were examined to determine if young wild boar entered the feeders (Ballesteros et al. 2009a) and if adult ones turned the stones (unpublished (a)

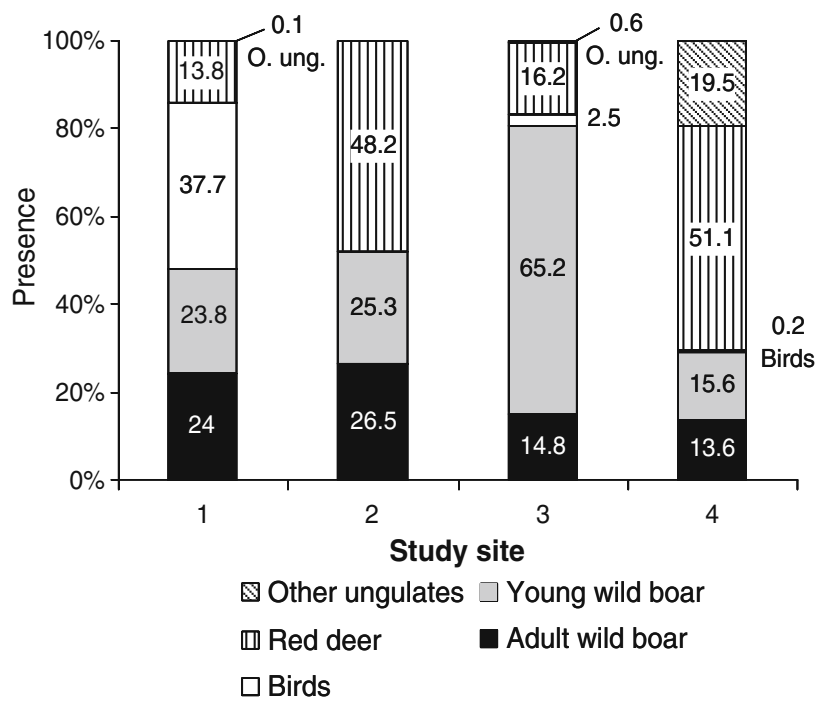

(b)

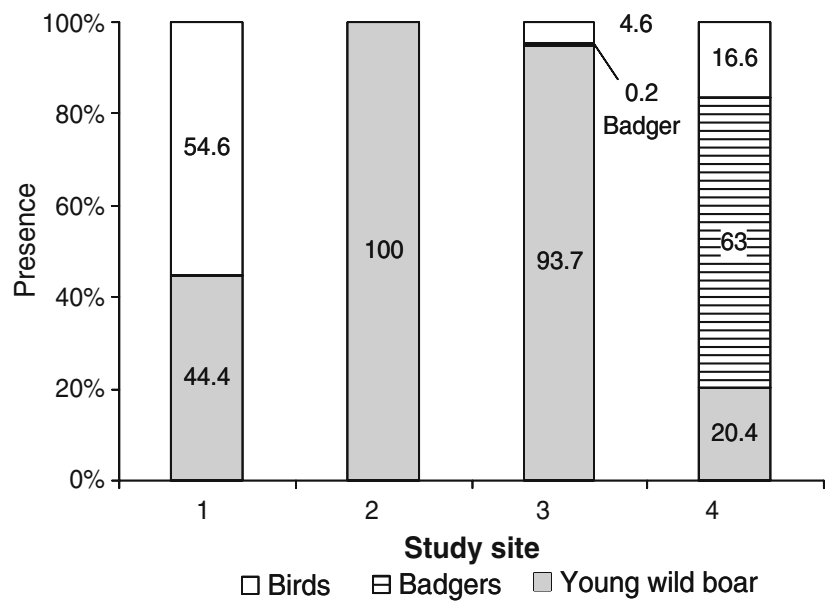

Fig. 1 Percent of boars by age and other species per study site a outside and $\mathbf{b}$ inside the selective feeders. Animal presence was determined from examining pictures taken with digital game cameras with infrared illumination on each site. In addition, red fox inside selective feeders at sites 1 and 3 and adult wild boar (sites 1 and 3), red deer (site 1), and red fox (sites 1 and 3) outside selective feeders represented $1 \%$ of the animals detected per site and were not included in graph. Other ungulates in the study sited included fallow deer, roe deer, and mouflon

observations). The fact that adult wild boar turned the stones did not mean that they consumed all the baits below them since other animals like young wild boar could gain access to the baits after adult ones turned the stones.

Baits

Baits used in the experiment had a hemispherical shape $(\varnothing 3.4 \times 1.6 \mathrm{~cm}, 10 \mathrm{~g})$. They consisted of piglet feed, 
paraffin, sucrose, and cinnamon-truffle powder attractant (Ballesteros et al. 2009b). A 0.2-mL polyethylene capsule filled with water was placed inside the baits to simulate the vaccine formulation.

IPA was diluted in ethanol to a concentration of $80 \mathrm{mg} / \mathrm{ml}$. Then, $0.5 \mathrm{ml}$ of the dilution was added to the surface of the recently prepared bait. The final concentration of IPA was $40 \mathrm{mg} /$ bait.

\section{Baiting field trial}

The field trial was conducted in summer 2008 (first baiting started on 4 August, last baiting on 30 September). Baits were set in two different places: baits directed to wild boar piglets were set inside selective feeders while baits directed to adult wild boar were set under pavel stones around the feeders $(<10-\mathrm{m}$ apart). The number of baits laid at each site was chosen based on the number of wild boar estimated by the managers and our independent abundance indexes, to result in a broad range of baiting intensities (Tables 1 and 2). According with the size of each site our baiting densities varied from 6.41 at site 1 to 27.3 per $\mathrm{km}^{2}$ at site 4 (in the case of the baits directed to wild boar piglets) whereas the baiting densities of baits directed to adult ones varied from 2.51 at site 1 to 9.09 per $\mathrm{km}^{2}$ at site 4 . Wild boar abundance indexes were estimated for each site as explained above (Acevedo et al. 2007). Indexes of abundance of $0.17,0.05,0.02$, and 0.28 were obtained for sites $1,2,3$, and 4 , respectively.

Two different markers were used to distinguish bait consumption inside or outside piglet feeders. Baits placed inside selective feeders contained ethyl-iophenoxic acid (Et-IPA) whereas baits placed under pavel stones contained the methyl analog of Et-IPA (Mt-IPA).
Two cycles of bait deployment were conducted at each site. In the first cycle, we placed 20 Et-IPA baits inside each selective feeder; whereas, three or four pavel stones (according to the density of wild boar) were placed next to each selective feeder, except at site 4 where due to the high density of wild boar we placed 50 Et-IPA baits inside each feeder and eight to nine stones per feeder. Two Mt-IPA baits were placed under each stone. Baits were delivered together with piglet feed in order to attract the animals and favor bait consumption. Four days after baiting we revisited the selective feeders and pavel stones to record complete or incomplete bait consumption and the number of intact and chewed capsules found. All digital cameras were checked and pictures downloaded for further analysis. Three days after the first cycle examination finished, the procedure was repeated (second cycle of bait deployment).

Animal samples from the baiting field trial

Hunter-harvested wild boar and non-target animals (red deer (Cervus elaphus) and mouflon (Ovis aries musimon)) from the sites in which baits were placed were blood sampled. Also, wild boar from an estate next to site 1 were blood sampled. In this estate, no marked baits were delivered. The objective was to check whether emigration could happen between closed estates.

Animals were legally hunted from October 2008 to February 2009. Blood samples were obtained post-mortem from the thoracic cavity. These were centrifuged to separate serum. Sera were placed in labeled tubes and stored at $-20^{\circ} \mathrm{C}$ until IPA detection by LC/ESI-MS as described by Jones (1994) and Wiles and Campbell (2006) with some modifications. Briefly, wild boar serum $(0.1 \mathrm{ml})$ was mixed with $0.63 \mathrm{ml}$ of acetonitrile and $20 \mu \mathrm{l}$ of buthyl-IPA

Table 2 Number of baits placed and consumed (consumption percentage) for each cycle

\begin{tabular}{|c|c|c|c|c|c|c|c|c|}
\hline \multirow[b]{2}{*}{ Site $^{\mathrm{a}}$} & \multicolumn{2}{|c|}{ No. Et-IPA baits placed } & \multicolumn{2}{|c|}{ No. Et-IPA baits consumed } & \multicolumn{2}{|c|}{ No. Mt-IPA baits placed } & \multicolumn{2}{|c|}{ No. Mt-IPA baits consumed } \\
\hline & Cycle 1 & Cycle 2 & Cycle 1 & Cycle 2 & Cycle 1 & Cycle 2 & Cycle 1 & Cycle 2 \\
\hline 1 & $\begin{array}{l}440^{\mathrm{b}} \\
6.41^{\mathrm{c}} / 37.7^{\mathrm{d}}\end{array}$ & $\begin{array}{l}540 \\
7.87^{\mathrm{c}} / 46.3^{\mathrm{d}}\end{array}$ & $400(90.9 \%)$ & $486(90.0 \%)$ & $\begin{array}{l}172^{\mathrm{b}} \\
2.51^{\mathrm{c}} / 14.7^{\mathrm{d}}\end{array}$ & $\begin{array}{l}204 \\
2.97^{\mathrm{c}} / 17.5^{\mathrm{d}}\end{array}$ & $158(91.2 \%)$ & $193(94.6 \%)$ \\
\hline 2 & $\begin{array}{l}320 \\
9.79 / 195.8\end{array}$ & $\begin{array}{l}320 \\
9.79 / 195.8\end{array}$ & $174(54.4 \%)$ & $116(36.2 \%)$ & $\begin{array}{l}108 \\
3.30 / 66.1\end{array}$ & $\begin{array}{l}108 \\
3.30 / 66.1\end{array}$ & $78(72.2 \%)$ & $59(54.6 \%)$ \\
\hline 3 & $\begin{array}{l}280 \\
13.4 / 67\end{array}$ & $\begin{array}{l}280 \\
13.4 / 67\end{array}$ & $268(95.7 \%)$ & $280(100 \%)$ & $\begin{array}{l}96 \\
4.6 / 23.0\end{array}$ & $\begin{array}{l}96 \\
4.6 / 23.0\end{array}$ & $83(86.4 \%)$ & $96(100 \%)$ \\
\hline 4 & $\begin{array}{l}300 \\
27.3 / 97.5\end{array}$ & $\begin{array}{l}300 \\
27.3 / 97.5\end{array}$ & $223(74.3 \%)$ & $207(69.0 \%)$ & $\begin{array}{l}100 \\
9.09 / 32.5\end{array}$ & $\begin{array}{l}100 \\
9.09 / 32.5\end{array}$ & $100(100 \%)$ & $100(100 \%)$ \\
\hline
\end{tabular}

\footnotetext{
${ }^{\mathrm{a}}$ Twenty and 50 baits were disposed in sites 1-3 and 4, respectively for each cycle

${ }^{\mathrm{b}}$ In the first cycle, five selective feeders were not visited by animals during the pre-baiting period. Therefore, no baits were placed inside them

${ }^{\mathrm{c}}$ Bait density per square kilometer

${ }^{\mathrm{d}}$ Bait density per wild boar, calculated as [baits density per square kilometer] $\div$ [wild boar abundance index]
} 
as internal standard ( $10 \mathrm{ng} / \mu \mathrm{l}$ in acetonitrile). The mixture was vortexed during 5-10 s, and then $0.2 \mathrm{ml}$ of a sodium tungstate dihydrate solution $(10 \%, w / v$ in water) and $0.2 \mathrm{ml}$ of sulphuric acid $0.33 \mathrm{M}$ were added. The resultant mixture was vortexed during $10 \mathrm{~min}$ at a high speed $(2,500 \mathrm{rpm})$ and cooled for $20 \mathrm{~min}$ at $-20^{\circ} \mathrm{C}$ until two phases were separated. Then it was centrifuged at $5,000 \times g$ at $4^{\circ} \mathrm{C}$ for $10 \mathrm{~min}$ and $0.6 \mathrm{ml}$ of the upper acetonitrile phase was transferred to a glass vial for LC/MS analysis (Ballesteros et al. 2010).

\section{Statistical analysis}

Contact rates were compared using $\chi^{2}$ tests. We designed logistic models to test the statistical effect of sex (categorical predictor) and age class (categorical predictor, young vs. adult) on the probability of presence of any marker (Et-IPA and Mt-IPA as dependent variables, respectively; absence $=0$, presence $=1$ ) and its combinations (combination of Et-IPA and Mt-IPA and of Et-IPA or Mt-IPA as dependent variables, respectively; absence $=0$, presence $=1$ ). These models were separately built for study sites 1,2 , and 3 , since sampling size and composition did not allow for comparison in site 4 . The significant level was set at $p<0.05$. We used SPSS 17.0 statistical software.

\section{Results}

Bait consumption and targeted species

After examinations of feeders and pavel stones we recorded the number of baits that had disappeared (consumed) and the number of capsules found as well as their state (chewed or intact). Intact capsules had water inside them.

The number of baits (both Et-IPA and Mt-IPA treated baits) placed and the number of baits consumed at each site is summarized in Table 2. Two sites were found where the proportion of consumed baits was high both inside feeders and under pavel stones $(>90 \%$, sites 1 and 3$)$. Site 2 presented lower proportions of consumed baits both inside the feeder and under pavel stones. Finally, site 4 presented moderate rates of bait consumption inside the feeders (averaging 74.3\%) and a total success when baits were placed under pavel stones $(100 \%)$. The percentages of consumption were similar when comparing the first and the second cycle trials for a given site and way of bait disposal (Table 2).

The number of intact and chewed capsules found at each site is recorded in Table 3. It was likely that capsules found inside selective feeders would correspond to ethylIPA-marked baits (baits targeted to wild boar piglets). Except for capsules found inside feeders in site 4, over 70\% of the capsules were chewed, being remarkable that over $90 \%$ of them (both inside and outside feeders) were chewed in site 1 (Table 3).

The relative frequency of selective feeder visits by different animal species was determined at each site (Fig. 1). Inside selective feeders, young wild boar ( $<8$ months of age, as established from picture examination and maximum grid width of $30 \mathrm{~cm}$ ) were detected more frequently than adult (over 8 months old) wild boar $\left(\chi^{2}=2,394, \chi^{2}=630, \chi^{2}=3,338\right.$, and $\chi^{2}=156$ in sites 1 to 4 , respectively; $p<0.05$ ). Adult wild boar (only detected in sites 1 and 3 ) and red deer (only found in site 1) detected inside the feeders represented $<1 \%$ of the visits per site. This finding was due to accidental circumstances when the shadowing cover or the metal grid was damaged. Birds and other animal species such as the Eurasian badger (Meles meles) were detected and were more abundant in sites 1 and 4 , respectively. At site 4, young wild boar were detected inside three of six feeders, while badgers were detected in all six feeders. Timing of feeder visits by both species was similar. Wild boar detection declined while badger detection increased between the start and the end of the bait deployment trials (data not shown).

Outside feeders, a wider range of species such as wild boar, red deer, small-sized birds, red fox (Vulpes vulpes), roe deer (Capreolus capreolus), fallow deer (Dama dama), mouflon, and badger were detected (Fig. 1). In sites 1 and 3 , wild boar (both adult and young) were detected more frequently $(p<0.05)$ when compared to red deer, red fox,
Table 3 Number of intact and chewed capsules found at each site

\begin{tabular}{|c|c|c|c|c|c|}
\hline \multirow[b]{3}{*}{ Site } & \multicolumn{4}{|c|}{ No. of intact capsules/chewed capsules } & \multirow{3}{*}{$\begin{array}{l}\text { Percentage chewed; \% } \\
\text { inside/outside }\end{array}$} \\
\hline & \multicolumn{2}{|c|}{ Inside feeders } & \multicolumn{2}{|c|}{ Outside feeders } & \\
\hline & Cycle 1 & Cycle 2 & Cycle 1 & Cycle 2 & \\
\hline 1 & $1 / 26$ & $2 / 31$ & $1 / 30$ & $8 / 88$ & $95 / 92.9$ \\
\hline 2 & $5 / 51$ & $1 / 26$ & $19 / 56$ & $5 / 26$ & $92.8 / 77.3$ \\
\hline 3 & $11 / 26$ & $36 / 93$ & $10 / 14$ & $24 / 125$ & $71.2 / 80.3$ \\
\hline 4 & $138 / 11$ & $227 / 5$ & $0 / 30$ & $0 / 45$ & $4.2 / 100$ \\
\hline
\end{tabular}


and roe deer. In site 2, no significant differences were found between the detection frequency of wild boar and red deer $\left(\chi^{2}=2.88, p=0.09\right)$. In site 4 , the presence of wild boar was significantly lower than that of red deer $\left(\chi^{2}=1,131\right.$, $p<0.05$ ) whereas it was significantly higher than that of red fox, mouflon, roe deer, and badger $\left(\chi^{2}=3,830, \chi^{2}=744\right.$, $\chi^{2}=2,246$ and $\chi^{2}=3,827$, respectively; $p<0.05$ ). Adult and young wild boar were found in similar frequencies outside selective feeders in sites 1 and 2, but young wild boar were significantly more frequent in sites 3 and $4\left(\chi^{2}=1971.0\right.$ and $\chi^{2}=17.74$, respectively; $p<0.05$ ).

Overall, artificial stones were turned in 115 cases. In $71.3 \%$ of the cases, adult wild boar turned the stones, $24.4 \%$ were turned by young wild boar (all of them close to 6 months of age), and only $4.3 \%$ were turned by red deer. Piglets and juveniles were often pictured roaming close to adult females that turned the stones.

Presence of methyl- and ethyl-IPA in animal serum

The presence of methyl- and ethyl-IPA was determined in the serum of sampled wild boar (Fig. 2). A total of 39, 34, 26, and 17 wild boar were sampled at sites 1, 2, 3, and 4, respectively. The number and age class of animals sampled depended on the number of animals hunted at each estate so only low percentages of the total population could be sampled (between $8.5 \%$ and $17.0 \%$ ). The proportion of wild boar showing methyl- or/and ethyl-IPA markers in serum ranged from $11.5 \%$ in site 3 to $56.4 \%$ in site 1 . When attending to age classes, $72.7 \%$ of young individuals (estimated to be $<8$ months when baits were disposed) from study site 1 presented any or both markers, and this rate decreased in sites $4(40.0 \%), 2(31.6 \%)$, and $3(12.6 \%)$. It is remarkable that the predominant marker in young wild boar from site 1 was Et-IPA whereas in site 4 it was MtIPA. For adults, a similar trend was found with sites 1 and 4 presenting the highest proportion of wild boar showing methyl- or/and ethyl-IPA markers in serum (up to $40.0 \%$ ). Again, Mt-IPA predominated in the study site 4. Agerelated differences in the presence of serum markers were found in site 2 only where the proportion of adult wild boar with serum markers was less than that of young animals $\left(\chi^{2}=4.24 ; p=0.04\right)$. However, wild boar of all ages and sexes appeared equally likely to consume baits containing IPA since logistic models for sites 1, 2, and 3 did not reveal sex or age effects on the probability of presence of any marker (and combinations).

A total of 43 non-target animals were sampled at the four sites to determine species-specific consumption of baits. Twenty-six red deer from site 1 were analyzed, two of them showing low concentrations of Mt-IPA in serum $(<0.1 \mathrm{ng} / \mu \mathrm{l})$. Five and ten red deer were sampled at sites 2 and 3, respectively and none of them showed methyl- or ethyl-IPA

\section{(a)}

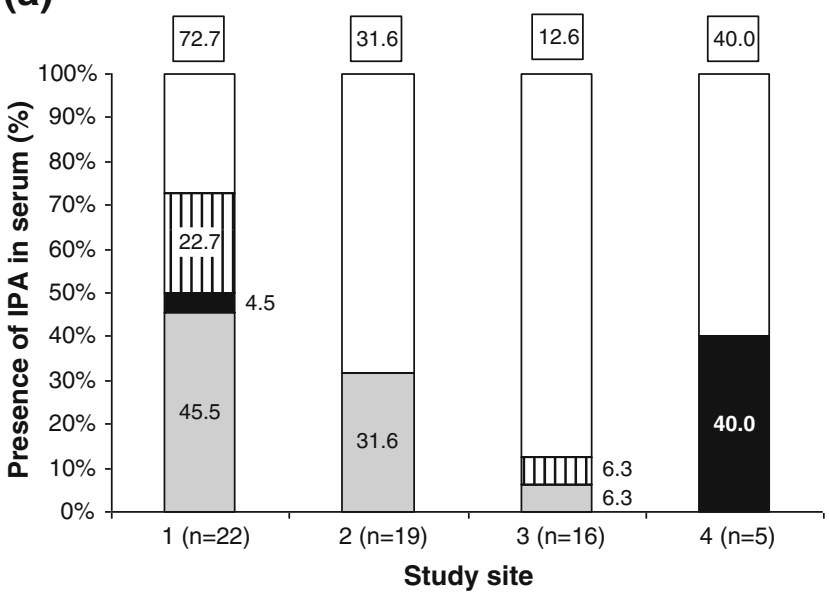

(b)

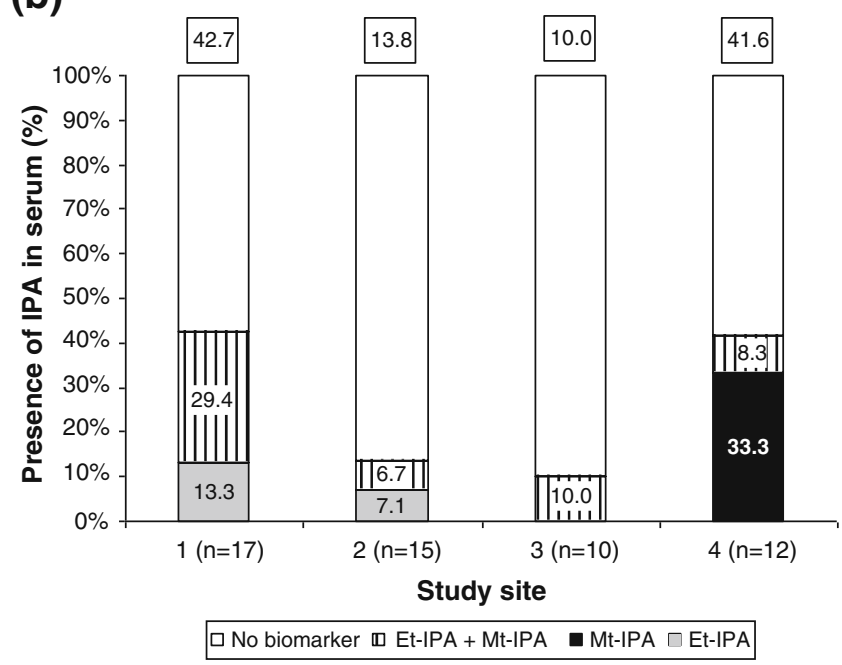

Fig. 2 Numbers of wild boar sampled at each study site and percentages of them showing only Et-IPA, only Mt-IPA, or both markers in serum according to the age (a refers to young wild boar whereas $\mathbf{b}$ refers to adult animals). The boxes on the top of the bars indicate the percentage of wild boar that showed any marker in serum (Et-IPA, Mt-IPA, or both)

in serum. Finally, two mouflons were sampled at site 4 and did not show any marker in serum. Thirty-five wild boar were sampled from an estate next to site 1 where marked baits were not delivered. None of them showed any marker in its serum.

\section{Discussion}

The proportion of free-living wild boar consuming two types of marked baits directed to adult and juvenile animals was determined. Variable oral-bait delivery success to wild boar was obtained among the four study sites where the baiting trials were conducted, ranging from a minimum of $12.6 \%$ to a promising $72.7 \%$ of juveniles having eaten marked baits, most of them (Fig. 2a) directed to wild boar piglets inside selective feeders. 
The examinations conducted at each site after bait deployment showed that the proportion of consumed baits in two sites was high $(>90 \%)$ both inside feeders and under the heavy pavel stones (sites 1 and 3; Table 2). However, in site 4 only moderate rates of bait consumption were obtained inside the feeders (Table 2). In this site, badgers predominated inside feeders, probably preventing young wild boar from getting inside feeders. This observation merits further research, since our results suggest that feeding wild boar may actually benefit badgers, with potential consequences regarding TB epidemiology in multi-host systems. Inside selective feeders, young wild boar were more frequently detected than adult wild boar. This result confirms the efficacy of selective feeders to deliver baits to young wild boar (Ballesteros et al. 2009a). Birds, highly abundant inside feeders in site 1 , have been demonstrated to have no effects on the integrity and persistence of baits (Ballesteros et al. 2009a), which was also confirmed in the present study. Outside feeders, a wider range of species was detected, being the wild boar (both adult and young) and red deer the most frequently found in accordance with the distribution and abundance of both species (Fig. 1; Acevedo et al. 2005, 2007). For instance, red deer locally presented even higher presence figures than wild boar, which may relate to higher densities of deer in the study areas (Acevedo et al. 2008).

Pavel stones were tested as a bait delivery method to adult wild boar. In most cases, stones were turned by adult wild boar and less than 5\% were due to non-target species such as red deer. In these cases, we observed that stones probably had not been appropriately buried in the ground due to the hard soil. In fact, in these cases animals displaced rather than turned the stones. Therefore, this method may be optimized to selectively deliver baits to adult wild boar.

From camera pictures it was not possible to visualize the individual baits since cameras only provide a punctual image, which do not always capture the moment when the animal takes the bait. So, we could not assess which animals consumed them. This information was only used to characterize the activity around the bait release points.

We observed in previous experiments that wild boar can get immunized by having oral mucosal contact with vaccines (Ballesteros et al. 2009b, c). So, it is not necessary that animals swallow the capsules to produce an immune response. A high proportion of chewed capsules were found (Table 3), thus confirming previous results on bait performance as a vehicle for liquid-based formulations targeting the oral mucosa (Ballesteros et al. 2009a, b). Nonetheless, only a low proportion of capsules found inside feeders in site 4 were chewed. This result was probably due to the predominant use of the selective feeders at this site by badgers rather than by young wild boar. It is almost impossible to avoid badgers entering the feeders. However, apparently, badgers do not chew these capsules as efficiently as wild boar do (Ballesteros et al. 2009a) so it is unlikely that badgers could have contact with the vaccine. These results confirmed the selectivity of the delivery methods for wild boar, although badgers could interfere locally with the wild boar bait uptake rate. However, in Spain, badgers present usually low densities in areas where bTB has become a problem that involves wild boar as the main reservoir (Naranjo et al. 2008; Sobrino et al. 2008).

Biomarker detection rate estimations were based on low sample sizes, given by the limited number of wild boar harvested in the four study sites $(<10 \%$ of the estimated total population in all cases). Thus, results obtained in this study need to be considered with caution. A $72.7 \%$ of young wild boar in study site 1 presented IPA marker in their serum, being Et-IPA (disposed in baits inside feeders) the predominant marker whereas $40 \%$ of young wild boar in site 4 presented only Mt-IPA (disposed in baits under stones; see Fig. 2). Similar findings were found for adult wild boar in sites 1 and 4, although with lower proportions of animals with serum markers. These results could be explained by the fact that young wild boar can forage around feeders together with adult females, gaining access to the baits placed below the stones after they are turned by adults. Conversely, some adult wild boar could gain access to baits placed inside feeders. A few cases of adult wild boar introducing their heads inside the metal grid were observed in pictures taken at site 1 . So, these animals could consume some of the baits directed to young wild boar. In addition, young wild boar could move some baits or bait fragments outside the feeder, a detail that is difficult to evidence with camera trapping. These facts indicate that selective feeders would need to be improved to avoid adult wild boar accessing the baits placed inside them, for example increasing their side size from 1 to $2 \mathrm{~m}$ or changing their triangular shape to a square one.

The low concentrations of IPA found in two red deer can be due to contact with remains of bait but not to whole bait consumption.

Bait delivery studies have used concentrations of IPA between 20 and $40 \mathrm{mg} /$ bait (Fletcher et al. 1990; Mitchell 1998; Fleming et al. 2000; Campbell et al. 2006). Twenty milligrams of IPA per bait may be insufficient to detect bait consumption in adult animals or when they consume one bait only (Cowled et al. 2008). Therefore, higher amounts of IPA (40 mg/bait) as used herein may give more reliable estimations of bait uptake (Cowled et al. 2008). The proportion of wild boar (young or adult) showing any marker in the serum or the combination of both strongly varied among study sites. The percentages of wild boar or feral pigs showing serum markers in previous bait delivery experiments varied from $31 \%$ to $95 \%$ depending on the study site, density of target animals and baiting density (baits per square kilometer; 
Fletcher et al. 1990; Mitchell 1998; Fleming et al. 2000; Campbell et al. 2006). In the present study, baiting densities varied from $2.51 \mathrm{Mt}$-IPA-marked baits $/ \mathrm{km}^{2}$ in site 1 to 27.3 Et-IPA-marked baits $/ \mathrm{km}^{2}$ in site 4 . These baiting densities were lower than those used in previous studies in other countries (e.g., 68 baits $/ \mathrm{km}^{2}$ in Campbell et al. (2006)), where feral pig densities are lower than wild boar densities in Mediterranean Spain (Naranjo et al. 2008). Therefore, in future experiments it would be desirable to use higher baiting densities to target a higher percentage of the wild boar population.

Additionally, other factors that could affect bait consumption such as the density of feeding points, the wild boar abundance in relation to the density of feeding points, the number of disposed baits at each feeder, the interference/competence with other bait-consuming species, and the population variations in bait acceptance and habituation to feeders should be considered in future experiments. In fact, in both sites where the pre-baiting period lasted longer ( $\geq 5$ weeks), the results of bait consumption by wild boar were better. This may indicate that wild boar were more accustomed to use feeders in these sites. O'Brien and Lukins (1988) and Saunders et al. (1990) emphasized the need for a sufficient pre-feeding regime prior to a trapping or poisoning program.

Finally, the spatial-temporal population dynamics of wild boar in the period between bait delivery and sampling, that is, immigration-emigration, could introduce some bias in the access to the population actually present at delivery time. Nonetheless the only estate where hunting occurred during the study period, potentially causing increased wild boar movements (Keuling et al. 2008), was site 1, where the highest marker presence was detected. The regular hunting season started at least 1.5 months after bait deployment in the remaining study sites, and therefore we do not suspect much movement due to these circumstances. This was further supported by analyzing samples from wild boar captured in an estate contiguous to site 1, finding no IPA-marked individuals. Site 4 was also impermeable for any ungulate immigration. Therefore, wild boar populations in sites 1 and 4 were highly fixed spatially. In contrast, the fences in sites 2 and 3 were quite permeable, suggesting that wild boar immigration-emigration movements were more likely, limiting apparent bait deployment success (due to immigration) or maker detectability (due to emigration).

In conclusion, the results obtained in these experiments showed that bait delivery systems used for young and adult wild boar were effective in targeting the desired species but not as effective in targeting the desired age groups since in a few cases adults got baits placed inside the selective feeders and young wild boar got baits placed under pavel stones after adult ones turned them. Variable results were obtained in the percentage of animals that ingested the baits
(Table 2, Fig. 2). Future experiments should test higher baiting densities and longer pre-baiting periods to increase baiting success and thus the efficacy of wild boar baiting strategies as a population or disease management tool in Spanish Mediterranean woodlands.

Acknowledgements We thank many colleagues from IREC for their technical assistance. Caterina Falconi, Luca Carrel, Jesús Carrasco, and Mauricio Durán helped in the field. Pablo R. Camarero helped in the IPA determination. We thank Bernardo Herrera for his help during field work. We also thank the managers of Quintos de Mora, Rosario, and Riofrio public estates for allowing access to the study areas, and the guards for helping during field work. This study was supported by grants from Instituto Nacional de Investigación y Tecnología Agraria y Alimentaria (INIA) (Project FAU 2006-00017-C03-01), Consejería de Educación y Ciencia, Junta de Comunidades de Castilla-La Mancha (JCCM) (projects PAI 06-0046-5285 and 07-0062-6611), EU FP7 Grant TB-STEP 212414; the Grupo Santander and the Fundación Marcelino Botín, Spain.

\section{References}

Acevedo P, Vicente J, Alzaga V, Gortázar C (2005) Relationship between bronchopulmonary nematode larvae and relative abundances of Spanish ibex (Capra pyrenaica hispanica) from Castilla-La Mancha, Spain. J Helminthol 79:113-118

Acevedo P, Vicente J, Hofle U, Casinello J, Ruiz-Fons F, Gortázar C (2007) Estimation of European wild boar relative abundance and aggregation: a novel method in epidemiological risk assessment. Epidemiol Infect 135:519-527

Acevedo P, Ruiz-Fons F, Vicente J, Reyes-Garcia AR, Alzaga V, Gortazar C (2008) Estimating red deer abundance in a wide range of management situations in Mediterranean habitats. J Zool $276: 37-47$

Astwood EB (1957) Occurrence in the sera of certain patients of large amounts of a newly isolated iodine compound. Trans Assoc Am Physicians Philadelphia 7:183-191

Baer GM (1976) The oral rabies immunization of foxes and dogs with sausage baits. Dev Biol Stand 33:417-423

Ballesteros C, Pérez de la Lastra JM, de la Fuente J (2007) Recent developments in oral bait vaccines for wildlife. Recent Pat Drug Deliv Formul 1:230-235

Ballesteros C, Carrasco-García R, Vicente J, Carrasco J, Lasagna A, de la Fuente J, Gortázar C (2009a) Selective piglet feeders improve age-related bait specificity and uptake rate in overabundant Eurasian wild boar populations. Wildl Res 36:203-212

Ballesteros C, Gortázar C, Canales M, Vicente J, Lasagna A, Gamarra JA, Carrasco-García R, de la Fuente J (2009b) Evaluation of baits for oral vaccination of European wild boar piglets. Res Vet Sci 86:388-393

Ballesteros C, Garrido JM, Vicente J, Romero B, Galindo RC, Minguijón E, Villar M, Martín-Hernando MP, Sevilla I, Juste R, Aranaz A, de la Fuente J, Gortázar C (2009c) First data on Eurasian wild boar response to oral immunization with BCG and challenge with a Mycobacterium bovis field strain. Vaccine 27:6662-6668

Ballesteros C, Camarero PR, Cristòfol C, Vicente J, Gortázar C, de la Fuente J, Mateo R (2010) Analysis by LC/ESI-MS of iophenoxic acid derivatives and evaluation as markers of oral baits to deliver pharmaceuticals to wildlife. J Chromatogr B 878:1997-2002 
Brauer A, Lange E, Kaden V (2006) Oral immunisation of wild boar against classical swine fever: uptake studies of new baits and investigations on the stability of lyophilised $\mathrm{C}$ - strain vaccine. Eur J Wildl Res 52:271-276

Campbell TA, Lapidge SJ, Long DB (2006) Using baits to deliver pharmaceuticals to feral swine in Southern Texas. Wildl Soc Bull 34:1184-1189

Cross ML, Buddle BM, Aldwell FE (2007) The potential of oral vaccines for disease control in wildlife species. Vet J 174:472480

Cowled BD, Gifford E, Smith M, Staples L, Lapidge SJ (2006) Efficacy of manufactured PIGOUT ${ }^{\circledR}$ baits for localised control of feral pigs in the semi-arid Queensland rangelands. Wildl Res $33: 427-437$

Cowled BD, Lapidge SJ, Smith MI, Staples LD (2008) Vaccination of feral pigs (Sus scrofa) using iophenoxic acid as a simulated vaccine. Aust Vet J 86:50-55

Farry SC, Henke SE, Beasom SL, Fearneyhough MG (1998) Efficacy of bait distributional strategies to deliver canine rabies vaccines to coyotes in Southern Texas. J Wildl Dis 34:23-32

Fleming PJS, Choquenot D, Mason RJ (2000) Aerial baiting of feral pigs (Sus scrofa) for exotic disease control in semi-arid rangelands of New South Wales. Wildl Res 27:531-537

Fletcher WO, Creekmore TE, Smith MS, Nettles VF (1990) A field trial to determine the feasibility of delivering oral vaccines to wild swine. J Wildl Dis 26:502-510

Gortázar C, Ferroglio E, Höfle U, Frölich K, Vicente J (2007) Diseases shared between wildlife and livestock: a European perspective. Eur J Wildl Res 53:241-256

Jones A (1994) High-performance liquid chromatographic determination of iophenoxic acid in serum. J Chromatogr B 654:293296

Kaden V, Hänel A, Renner Ch, Gossger K (2005) Oral immunisation of wild boar against classical swine fever in Baden-Württenberg: development of the seroprevalence based on the hunting bag. Eur J Wildl Res 51:101-107

Keuling O, Stier N, Roth M (2008) How does hunting influence activity and spatial usage in wild boar Sus scrofa L.? Eur J Wildl Res 54:729-737
Linhart SB, Kappeler A, Windberg LA (1997) A review of baits and bait delivery systems for free ranging carnivores and ungulates. In: Kreeger TJ (ed) Contraception in wildlife management. United States Department of Agriculture Technical Bulletin Number 1853, United States Government Printing Office, Washington, DC, pp 69-132

Massei G, Jones A, Platt T, Cowan DP (2009) Iophenoxic acid as a long-term marker for wild boar. J Wildl Manage 73:458-461

McIlroy JC, Braysher M, Saunders GR (1989) Effectiveness of a warfarin-poisoning campaign against feral pigs, Sus scrofa, in Namadgi National Park, A.C.T. Aust Wildl Res 16:195-202

Mitchell J (1998) The effectiveness of aerial baiting for control of feral pigs (Sus scrofa) in North Queensland. Wildl Res 25:297-303

Naranjo V, Gortázar C, Vicente J, de la Fuente J (2008) Evidence of the role of European wild boar as a reservoir of Mycobacterium tuberculosis complex. Vet Microbiol 127:1-9

O'Brien PH, Lukins BS (1988) Factors influencing the intake of sodium monofluoroacetate (compound 1080) by free-ranging feral pigs. Aust Wildl Res 15:285-291

Ruiz-Fons F, Vidal D, Vicente J, Acevedo P, Fernández-de-Mera IG, Montoro V, Gortázar C (2008) Epidemiological risk factors of Aujeszky's disease in wild boar (Sus scrofa) and domestic pigs in Spain. Eur J Wildl Res 54:549-555

Saunders G, Kay B, Parker B (1990) Evaluation of a warfarin poisoning programme for feral pigs (Sus scrofa). Aust Wildl Res 17:525-533

Shapiro MD (1953) A preliminary report on Teridax, a new cholecystographic medium. Radiology 60:687-690

Sobrino R, Martin-Hernando MP, Vicente J, Aurtenetxe O, Garrido JM, Gortazar C (2008) Bovine tuberculosis in a badger (Meles meles) in Spain. Vet Rec 163:159-160

Twigg LE, Lowe T, Martin G (2007) Bait consumption by, and 1080based control of, feral pigs in the Mediterranean climatic region of south-western Australia. Wildl Res 34:125-139

Vos A, Selhorst T, Schröder R, Mulder J (2008) Feasibility of oral rabies vaccination campaigns of young foxes (Vulpes vulpes) against rabies in summer. Eur J Wildl Res 54:763-766

Wiles MC, Campbell TA (2006) High-performance liquid chromatographic determination of iophenoxic acid in serum. J Chromatogr B $832: 144-157$ 